Article

\title{
Surface Passivation of Boron Emitters on n-Type Silicon Solar Cells
}

\author{
Ji Yeon Hyun ${ }^{1}$, Soohyun Bae ${ }^{1}$, Yoon Chung Nam ${ }^{1}$, Dongkyun Kang ${ }^{1}$, Sang-Won Lee ${ }^{1}$, \\ Donghwan Kim ${ }^{1,2}$, Jooyoung Park ${ }^{2, *}$, Yoonmook Kang ${ }^{2, *}$ and Hae-Seok Lee ${ }^{2, *}$ \\ 1 Department of Materials Science and Engineering, Korea University, 145 Anam-ro, Seongbuk-gu, \\ Seoul 02841, Korea \\ 2 KU-KIST GREEN School (Graduate School of Energy and Environment), Korea University, 145 Anam-ro, \\ Seongbuk-gu, Seoul 02841, Korea \\ * Correspondence: jy_park@korea.ac.kr (J.P.); ddang@korea.ac.kr (Y.K.); lhseok@korea.ac.kr (H.-S.L.)
}

Received: 30 May 2019; Accepted: 9 July 2019; Published: 10 July 2019

check for updates

\begin{abstract}
Al}_{2} \mathrm{O}_{3} / \mathrm{SiN}_{\mathrm{x}}$ stack passivation layers are among the most popular layers used for commercial silicon solar cells. In particular, aluminum oxide has a high negative charge, while the $\mathrm{SiN}_{\mathrm{x}}$ film is known to supply hydrogen as well as impart antireflective properties. Although there are many experimental results that show that the passivation characteristics are lowered by using the stack passivation layer, the cause of the passivation is not yet understood. In this study, we investigated the passivation characteristics of $\mathrm{Al}_{2} \mathrm{O}_{3} / \mathrm{SiN}_{\mathrm{x}}$ stack layers. To identify the hydrogenation effect, we analyzed the hydrogen migration with atom probe tomography by comparing the pre-annealing and post-annealing treatments. For chemical passivation, capacitance-voltage measurements were used to confirm the negative fixed charge density due to heat treatment. Moreover, the field-effect passivation was understood by confirming changes in the $\mathrm{Al}_{2} \mathrm{O}_{3}$ structure using electron energy-loss spectroscopy.
\end{abstract}

Keywords: surface passivation; hydrogenation; silicon solar cells; aluminum oxide; field-effect passivation; chemical passivation

\section{Introduction}

As the interest in renewable energy has recently increased, solar energy, in particular, has attracted attention as an energy source that can meet the explosive growth in energy demand. Of the various types of solar cells, silicon-based solar cells account for more than $90 \%$ of the total market. To secure the price competitiveness of silicon solar cells due to the recent decline in module prices, studies on highly efficient structures have been carried out, in addition to other efforts to lower the production costs $[1,2]$. To improve the conversion efficiency of silicon solar cells, wafer thickness reduction and surface passivation characteristics with increased emitter doping concentration are becoming more important. The surface passivation layer has two major roles. First, it eliminates dangling bonds on the surface, thus reducing surface re-defect losses. Second, an effect occurs due to the formation of an interfacial electric field by a fixed charge in the passivation layer. The main passivation layer comprises silicon oxide $\left(\mathrm{SiO}_{2}\right)$ and silicon nitride $\left(\mathrm{SiN}_{\mathrm{x}}\right)$ with a positive fixed charge, and aluminum oxide $\left(\mathrm{Al}_{2} \mathrm{O}_{3}\right)$ with a negative fixed charge $[3,4]$. Of these, $\mathrm{Al}_{2} \mathrm{O}_{3}$ is mainly used as a passivation film with a high density of fixed negative charge for lowly doped p-type or n-type silicon and highly doped p-type emitters [5,6]. $\mathrm{Al}_{2} \mathrm{O}_{3}$ thin films deposited by atomic layer deposition (ALD) are known to improve the characteristics of surface passivation by decreasing density of interface defect states $\left(\mathrm{D}_{\mathrm{it}}\right)$ and increasing the fixed charge density $\left(Q_{f}\right)$ through heat treatment [7-9]. $\mathrm{SiN}_{\mathrm{x}}$, which is mainly used as a capping layer, contains a large amount of hydrogen; therefore, hydrogen is used to passivate the dangling bonds present on the silicon surface [10,11]. It is used as a source to supply hydrogen and, at the same time, acts as an antireflective coating on the entire 
surface of a solar cell. This study was carried out to verify the passivation characteristics of $\mathrm{Al}_{2} \mathrm{O}_{3}$ and $\mathrm{SiN}_{\mathrm{x}}$ stack structures. We compared the implied Voc using pre-annealing and post-annealing treatments. To confirm the effects of chemical passivation, we compared the migration of hydrogen through atom probe tomography (APT) $[12,13]$. We also used capacitance-voltage (C-V) measurements to determine the field-effect passivation characteristics. The structural changes in $\mathrm{Al}_{2} \mathrm{O}_{3}$ were analyzed to determine the increase in the fixed charge after the heat treatment.

\section{Materials and Methods}

\subsection{Preparation of Samples}

To investigate the chemical and field-effect passivation qualities of the $\mathrm{Al}_{2} \mathrm{O}_{3} / \mathrm{SiN}_{\mathrm{x}}$ film, n-type Czochralski (Cz) wafers were used (6 in diameter, $180 \mu \mathrm{m}$ thickness, $3-4 \Omega \cdot \mathrm{cm}$ resistivity). After cleaning the wafers by the standard Radio Corporation of America (RCA) cleaning procedure, they were textured with a $\mathrm{KOH}$ solution. An emitter with a sheet resistance of $110 \Omega / \mathrm{cm}^{2}$ was formed on both sides using boron tribromide $\left(\mathrm{BBr}_{3}\right)$ in a liquid propane furnace. To remove the borosilicate glass and native oxide, all samples were subjected to wet-chemical cleaning with a dilute HF solution before the deposition of $\mathrm{Al}_{2} \mathrm{O}_{3}$. To perform the $\mathrm{C}-\mathrm{V}$, electron energy-loss spectroscopy (EELS), and APT measurements, $\mathrm{n}$-type semiconductor wafers were used (6 in diameter, $500 \mu \mathrm{m}$ thickness). The passivation layers were deposited on one side.

\subsection{Passivation}

$\mathrm{Al}_{2} \mathrm{O}_{3}$ films of thickness $10 \mathrm{~nm}$ were deposited on both sides of the substrate by thermal ALD with trimethyl aluminum (TMA, $\left.\mathrm{Al}\left(\mathrm{CH}_{3}\right)_{3}\right)$ and $\mathrm{H}_{2} \mathrm{O}$ as precursors at $220^{\circ} \mathrm{C}$. After the deposition of the $\mathrm{Al}_{2} \mathrm{O}_{3}$ films, the samples were divided into two groups to confirm the effects of chemical and field-effect passivation. On half of the samples, $80 \mathrm{~nm} \mathrm{SiN}$ films were directly deposited onto the $\mathrm{Al}_{2} \mathrm{O}_{3}$ on both sides of the wafers using plasma-enhanced chemical vapor deposition (PECVD). After the deposition of the $\mathrm{SiN}_{\mathrm{x}}$ films, the samples were annealed under $\mathrm{N}_{2}$ for $15 \mathrm{~min}$ with a rapid thermal process in the temperature range of $400-600^{\circ} \mathrm{C}$, at intervals of $50^{\circ} \mathrm{C}$. On the other half of the samples, the annealing treatment was performed before deposition of the $\mathrm{SiN}_{\mathrm{x}}$ layer. The processing sequence is illustrated in Figure 1.

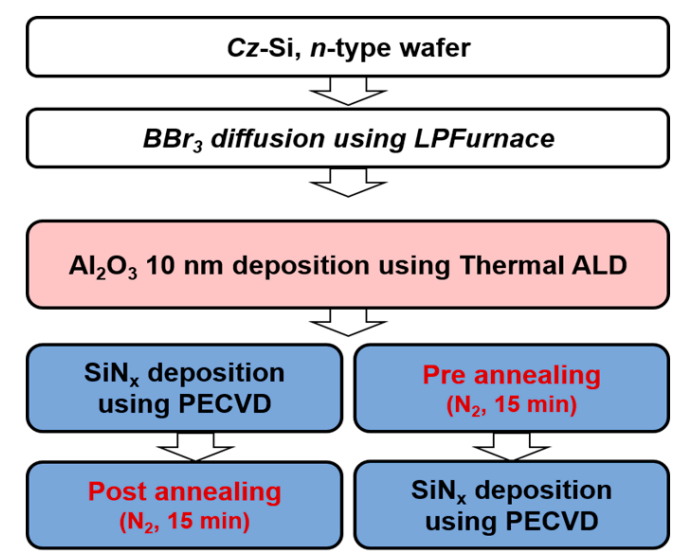

Figure 1. Processing sequence for pre-annealed and post-annealed samples.

\subsection{Measurements}

The implied Voc values were obtained from quasi-steady-state photoconductance (QSSPC, WCT-120) measurements and were used to compare the passivation characteristics of the pre-annealed and post-annealed samples. The sample structures are shown in Figure 2. The wafers used for the C-V, EELS, and APT measurements were polished on both sides and were $500 \mu \mathrm{m}$ thick. 


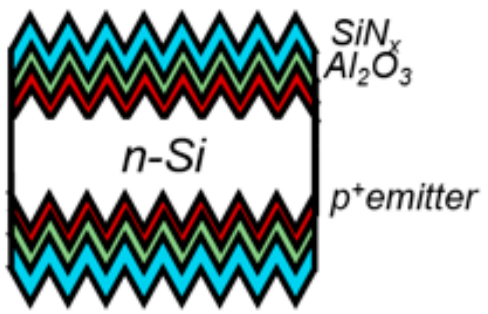

(a)

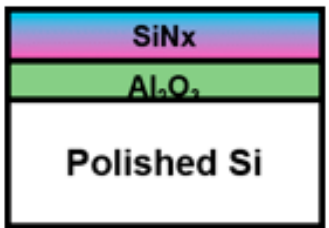

(b)

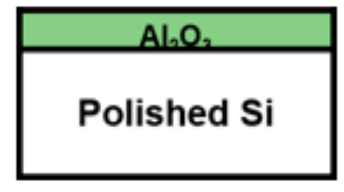

(c)

Figure 2. Cross-sectional schematics of the samples prepared for (a) quasi-steady-state photoconductance (QSSPC), (b) atom probe tomography (APT), and (c) electron energy-loss spectroscopy capacitance-voltage (EELS C-V) measurements.

\section{Results and Discussion}

\subsection{Implied $V o c$}

Figure 3 shows the implied Voc values of the pre-annealed and post-annealed samples with respect to the annealing temperature. The implied $V o c$ values of the pre-annealed and post-annealed samples were higher than those of the deposited $\mathrm{Al}_{2} \mathrm{O}_{3}$. Excluding the samples treated at $600{ }^{\circ} \mathrm{C}$, the post-annealed samples showed higher implied Voc values than the pre-annealed samples. One peculiar aspect is that the pre-annealed samples showed similar implied Voc values over the entire temperature range. On the contrary, the post-annealed samples showed a maximum implied Voc value at a certain temperature, above which the implied Voc tended to decrease with increasing temperature.

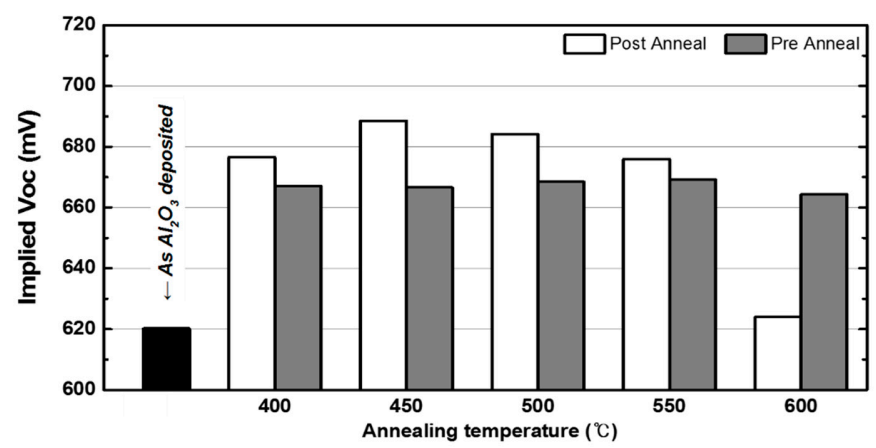

Figure 3. Implied Voc values of pre-annealed and post-annealed samples with different annealing temperatures.

This can be understood as a decrease in the passivation property due to the blistering phenomenon in the $\mathrm{Al}_{2} \mathrm{O}_{3} / \mathrm{SiN}_{X}$ stack structure [14,15]. To confirm the effects of chemical and field-effect passivation on the pre-annealed and post-annealed samples, we compared the migration of hydrogen through APT and examined the structural change of $\mathrm{Al}_{2} \mathrm{O}_{3}$ through EELS. Moreover, $Q_{f}$ was compared through the C-V measurements.

\subsection{Chemical Passivation: Atom Probe Tomography}

Research on hydrogen has been actively conducted to understand chemical passivation [16-19]. However, as hydrogen has a small mass and small size, the analysis methods are limited and difficult to perform. Therefore, through an analysis different from existing research methods we were able to understand the behavior of hydrogen. APT was performed to confirm the distribution of hydrogen at the interface between the silicon and $\mathrm{Al}_{2} \mathrm{O}_{3}$. The samples were polished to alleviate surface morphology issues. Figure $4 \mathrm{a}, \mathrm{b}$ show the transmission electron microscopy (TEM) images after pre-annealing and post-annealing, respectively. Meanwhile, Figure 4c,d show the atomic distributions of the pre-annealed and post-annealed samples treated at $500{ }^{\circ} \mathrm{C}$. The sample structure was $\mathrm{SiN}_{\mathrm{X}}-\mathrm{Al}_{2} \mathrm{O}_{3}-\mathrm{Si}$, in sequence from 
the surface to the silicon; the hydrogen, nitrogen, aluminum, and silicon atoms are represented by the pink, yellow, blue, and green colors, respectively. In the case of the pre-annealed sample, the interfaces between $\mathrm{SiN}_{\mathrm{x}} / \mathrm{Al}_{2} \mathrm{O}_{3} / \mathrm{Si}$ are clearly distinguished. However, in the case of the post-annealed sample, the interfaces are not, and hydrogen is widely distributed throughout the silicon. Figure $4 \mathrm{e}, \mathrm{f}$ show the hydrogen concentration along the depth direction from the surface. In the case of the post-annealed sample, the hydrogen concentration at the silicon and $\mathrm{Al}_{2} \mathrm{O}_{3}$ interface was approximately $20-30 \%$, which is higher than the hydrogen content $(\sim 2 \%)$ in the pre-annealed sample. Because $\mathrm{SiN}_{\mathrm{x}}$ was deposited using $\mathrm{SiH}_{4}$ and $\mathrm{NH}_{3}$ gas by PECVD, the $\mathrm{SiN}_{\mathrm{x}}$ film contains a high concentration of hydrogen. The post-annealing process was performed after the deposition of $\mathrm{SiN}_{\mathrm{x}}$; therefore, some of the hydrogen present in the $\mathrm{SiN}_{\mathrm{x}}$ effused out of the surface, whereas some of the hydrogen diffused into the silicon and $\mathrm{Al}_{2} \mathrm{O}_{3}$ interface, passivating the dangling bonds. However, it cannot be said that the pre-annealed sample did not undergo chemical passivation by hydrogen. Because the $\mathrm{Al}_{2} \mathrm{O}_{3}$ is deposited using TMA and $\mathrm{H}_{2} \mathrm{O}$ sources, it also contains a small amount of hydrogen.

(a)
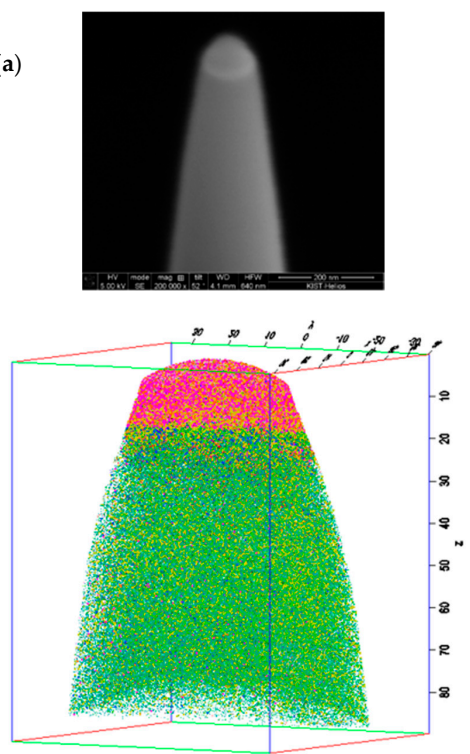

(c) (b)
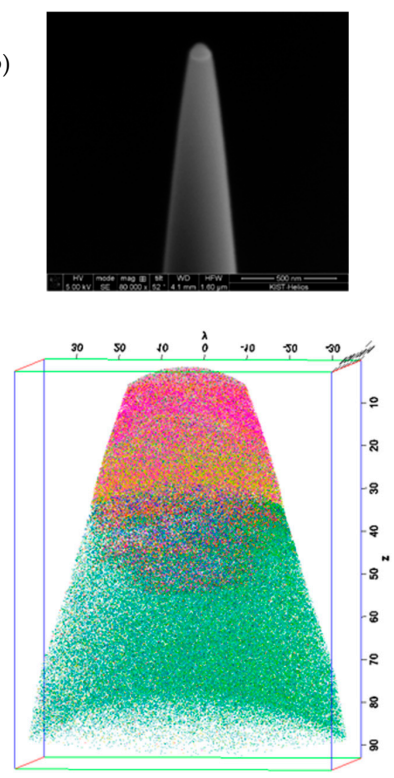

(d)
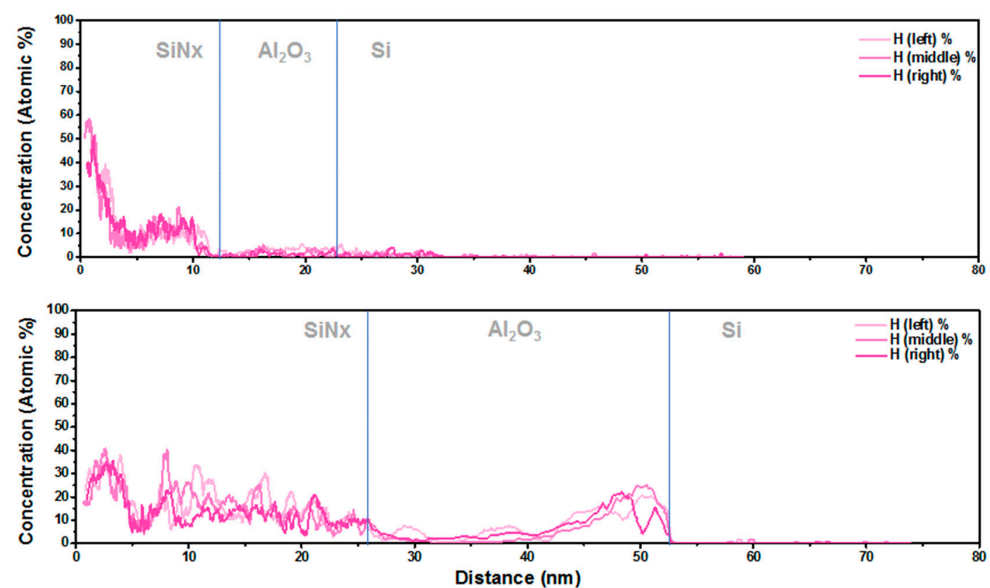

(e)

(f)

Figure 4. Atom probe tomography. Focused ion beam transmission electron microscopy images of (a) pre-annealed and (b) post-annealed samples. Three-dimensional atomic maps of (c) pre-annealed and (d) post-annealed samples. One-dimensional hydrogen concentration profiles of (e) pre-annealed and (f) post-annealed samples. 


\subsection{Analysis of $\mathrm{Al}_{2} \mathrm{O}_{3}$ Structure}

$\mathrm{C}-\mathrm{V}$ measurements were performed to confirm the characteristics of field-effect passivation with and without the heat treatment of $\mathrm{Al}_{2} \mathrm{O}_{3}$. The samples were characterized after the $10 \mathrm{~nm}$ thick $\mathrm{Al}_{2} \mathrm{O}_{3}$ was deposited and annealed at $500{ }^{\circ} \mathrm{C}$, the results of which were compared. The fixed charge was calculated by changing the flat band voltage based on the C-V graph. Figure 5a shows the change in the negative fixed charge before and after annealing. By comparing these results, it is observed that the $\mathrm{Al}_{2} \mathrm{O}_{3}$ film shows increased negative fixed charge after the heat treatment. Similar results were reported in many papers [19-23]. According to these, the negative fixed charge of $\mathrm{Al}_{2} \mathrm{O}_{3}$ results from its structural change. This can be confirmed by the bonding change of Al-O, Al-O-H and Si-O with X-ray photoelectron spectroscopy (XPS) analysis, as well as an analysis of the TEM images $[2,4,19,20,24]$. We confirmed the structural change of $\mathrm{Al}_{2} \mathrm{O}_{3}$ through EELS, showing it has both octahedral and tetrahedral structures. The closer to the silicon interface, the more tetrahedral sites exist owing to the effects of silicon oxide. When the structure changes from an electronically neutral octahedral structure to a tetrahedral structure, $\mathrm{Al}$ vacancies are formed and the vacancy of $\mathrm{Al}^{3+}$ provides a negative charge. In this study, we compared the relative amounts of the tetrahedral and octahedral structures of $\mathrm{Al}_{2} \mathrm{O}_{3}$ with respect to the depth from the surface before and after annealing. It can be seen from Figure $5 b$ that the ratio of Tetrahedral/Octahedral varies depending on the heat treatment. In the case of the sample without heat treatment, the tetrahedral ratio gradually increases from the surface to the interface. On the contrary, in the case of the heat-treated sample, the tetrahedral ratio is high for the entire $\mathrm{Al}_{2} \mathrm{O}_{3}$ film. The structural change to tetrahedral structure increases the negative fixed charge and increases the field-effect passivation effect.

(a)

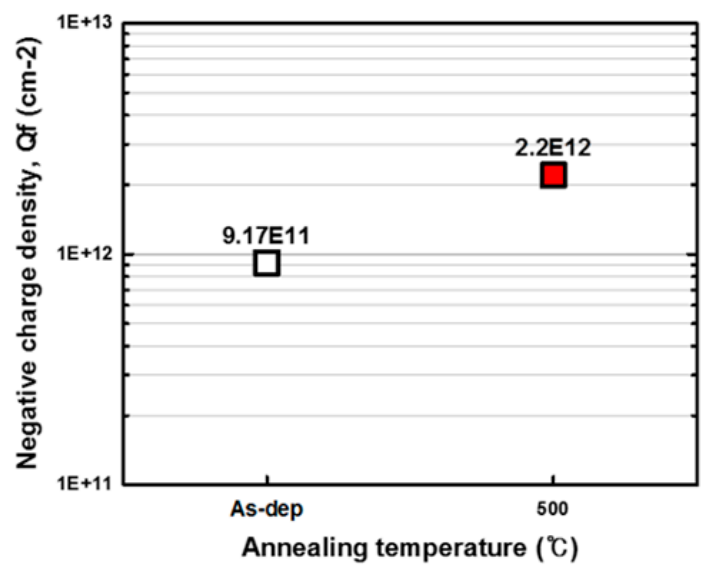

(b)

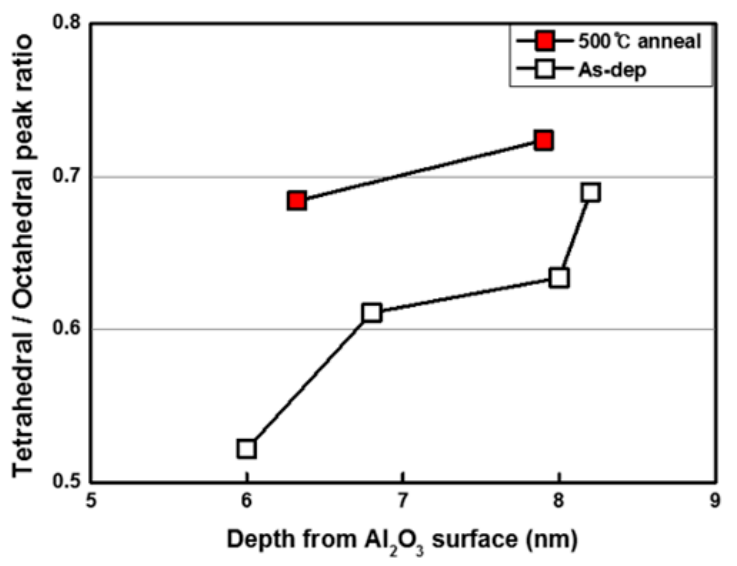

Figure 5. (a) C-V results for negative fixed charge density $\left(Q_{f}\right)$; (b) EELS depth analysis results for as-deposited $500{ }^{\circ} \mathrm{C}$ annealed samples.

\section{Conclusions}

To investigate the surface passivation characteristics of the $\mathrm{Al}_{2} \mathrm{O}_{3} / \mathrm{SiN}_{\mathrm{x}}$ stack layer, two aspects of chemical passivation and field effect passivation were studied using common analytical methods such as C-V and QSSPC and new analytical methods such APT and EELS. In order to verify the characteristics of passivation by heat treatment, implied Voc was measured and compared, and it increased at all heat treatment temperature ranges. To understand the chemical passivation, the hydrogen behavior was studied and the 3D mapping analysis showed that hydrogen was supplied from $\mathrm{SiN}_{\mathrm{x}}$. Particularly, when a sufficient amount of hydrogen was supplied from $\mathrm{SiN}_{\mathrm{x}}$ through post annealing, the hydrogen distribution increased to approximately $20 \%$ at the interface of $\mathrm{Al}_{2} \mathrm{O}_{3}$ and silicon. However, although hydrogen supply through post-annealing is also important, properties due to the heat treatment temperature must be considered. From C-V measurements and EEL results, it was 
confirmed that the negative fixed charge of $\mathrm{Al}_{2} \mathrm{O}_{3}$ came from the structural change of it. The ratio of the tetrahedral structure inside the $\mathrm{Al}_{2} \mathrm{O}_{3}$ film was increased about 1.5 times by the heat treatment.

Author Contributions: Conceptualization, J.Y.H., Y.K., and H.-S.L.; formal analysis, J.Y.H., S.B., Y.C.N., S.-W.L., D.K. (Dongkyun Kang), and Y.K.; project administration, D.K. (Donghwan Kim); writing—original draft, J.Y.H., and J.P.

Funding: This work was supported by the "Human Resources Program in Energy Technology" and the New \& Renewable Energy Core Technology Program of the Korea Institute of Energy Technology Evaluation and Planning (KETEP), funded by the Ministry of Trade, Industry, and Energy, Republic of Korea (No. 20154030200760), (No. 20188550000450). This research was also supported by the National Research Foundation of Korea (2017M1A2A2087351), funded by the Ministry of Science, ICT, and Future Planning of Korea.

Conflicts of Interest: The authors declare no conflict of interest.

\section{References}

1. Feldmann, F.; Bivour, M.; Reichel, C.; Hermle, M.; Glunz, S.W. Passivated rear contacts for high-efficiency n-type Si solar cells providing high interface passivation quality and excellent transport characteristics. Sol. Energy Mater. Sol. Cells 2014, 120, 270-274. [CrossRef]

2. Dingemans, G.; Kessels, W.M.M. Status and prospects of $\mathrm{Al}_{2} \mathrm{O}_{3}$-based surface passivation schemes for silicon solar cells. J. Vac. Sci. Technol. A 2012, 30, 040802. [CrossRef]

3. Richter, A. Aluminum Oxide for the Surface Passivation of High Efficiency Silicon Solar Cells: Technology and Advanced Characterization. Ph.D. Thesis, Fraunhofer Verl., Freiburg, Germany, 2015.

4. Hoex, B.; Gielis, J.; Van de Sanden, M.; Kessels, W. On the c-Si surface passivation mechanism by the negative-charge-dielectric $\mathrm{Al}_{2} \mathrm{O}_{3}$. J. Appl. Phys. 2008, 104, 113703. [CrossRef]

5. Saint-Cast, P.; Kania, D.; Hofmann, M.; Benick, J.; Rentsch, J.; Preu, R. Very low surface recombination velocity on p-type c-Si by high-rate plasma-deposited aluminum oxide. Appl. Phys. Lett. 2009, 95, 151502. [CrossRef]

6. Dingemans, G.; Van de Sanden, M.; Kessels, W. Influence of the deposition temperature on the c-Si surface passivation by $\mathrm{Al}_{2} \mathrm{O}_{3}$ films synthesized by ALD and PECVD. Electrochem. Solid State Lett. 2010, 13, H76-H79. [CrossRef]

7. Kaur, G.; Dwivedi, N.; Zheng, X.; Liao, B.C.; Peng, L.Z.; Danner, A.; Stangl, R.; Bhatia, C.S. Understanding surface treatment and $\mathrm{ALD} \mathrm{AlO}_{\mathrm{x}}$ thickness induced surface passivation quality of $\mathrm{c}-\mathrm{Si} \mathrm{Cz}$ wafers. IEEE J. Photovolt. 2017, 7, 1224-1235. [CrossRef]

8. Dingemans, G.; Terlinden, N.; Pierreux, D.; Profijt, H.; Van de Sanden, M.; Kessels, W. Influence of the oxidant on the chemical and field-effect passivation of $\mathrm{Si}$ by $\mathrm{ALD} \mathrm{Al}_{2} \mathrm{O}_{3}$. Electrochem. Solid State Lett. 2011, 14, H1-H4. [CrossRef]

9. Saint-Cast, P.; Benick, J.; Kania, D.; Weiss, L.; Hofmann, M.; Rentsch, J.; Preu, R.; Glunz, S.W. High-efficiency c-Si solar cells passivated with ALD and PECVD aluminum oxide. IEEE Electron Device Lett. 2010, 31, 695-697. [CrossRef]

10. Dingemans, G.; Engelhart, P.; Seguin, R.; Einsele, F.; Hoex, B.; Van de Sanden, M.; Kessels, W. Stability of $\mathrm{Al}_{2} \mathrm{O}_{3}$ and $\mathrm{Al}_{2} \mathrm{O}_{3} / \mathrm{a}-\mathrm{SiN}_{\mathrm{x}}: \mathrm{H}$ stacks for surface passivation of crystalline silicon. J. Appl. Phys. 2009, 106, 114907. [CrossRef]

11. Veith, B.; Werner, F.; Zielke, D.; Brendel, R.; Schmidt, J. Comparison of the thermal stability of single $\mathrm{Al}_{2} \mathrm{O}_{3}$ layers and $\mathrm{Al}_{2} \mathrm{O}_{3} / \mathrm{SiNx}$ stacks for the surface passiviation of silicon. Energy Procedia 2011, 8, 307-312. [CrossRef]

12. Seidman, D.N.; Stiller, K. An atom-probe tomography primer. MRS Bull. 2009, 34, 717-724. [CrossRef]

13. Weber, J. Fundamental Insights into the Radium Uptake into Barite by Atom Probe Tomography and Electron Microscopy; Forschungszentrum Jülich GmbH, Zentralbibliothek: Yulishi, Germany, 2017.

14. Vermang, B.; Goverde, H.; Lorenz, A.; Uruena, A.; Vereecke, G.; Meersschaut, J.; Cornagliotti, E.; Rothschild, A.; John, J.; Poortmans, J. On the blistering of atomic layer deposited $\mathrm{Al}_{2} \mathrm{O}_{3}$ as $\mathrm{Si}$ surface passivation. In Proceedings of the 37th IEEE Photovoltaic Specialists Conference (IEEE), Seattle, WA, USA, 19-24 June 2011; pp. 3562-3567.

15. Kim, J.E.; Bae, S.; Song, I.S.; Hyun, J.Y.; Lee, K.D.; Shin, S.H.; Kang, Y.; Lee, H.-S.; Kim, D. Effects of Annealing on Firing Stability of a $\mathrm{Al}_{2} \mathrm{O}_{3} / \mathrm{SiN}_{\mathrm{x}}$ Stack Passivation Layer for Crystalline Silicon Solar Cells. J. Nanosci. Nanotechnol. 2017, 17, 5050-5054. [CrossRef] 
16. Schnabel, M.; Van De Loo, B.W.; Nemeth, W.; Macco, B.; Stradins, P.; Kessels, W.; Young, D.L. Hydrogen passivation of poly-Si/SiOx contacts for $\mathrm{Si}$ solar cells using $\mathrm{Al}_{2} \mathrm{O}_{3}$ studied with deuterium. Appl. Phys. Lett. 2018, 112, 203901. [CrossRef]

17. Li, S.; Yang, N.; Yuan, X.; Liu, C.; Ye, X.; Li, H. Hydrogen induced interface passivation in atomic layer deposited $\mathrm{Al}_{2} \mathrm{O}_{3}$ films and $\mathrm{Al}_{2} \mathrm{O}_{3} / \mathrm{SiO}_{2}$ stacks. Mater. Sci. Semicond. Process. 2018, 83, 171-174. [CrossRef]

18. Sopori, B.L.; Deng, X.; Benner, J.P.; Rohatgi, A.; Sana, P.; Estreicher, S.K.; Park, Y.K.; Roberson, M.A. Hydrogen in silicon: A discussion of diffusion and passivation mechanisms. Sol. Energy Mater. Sol. 1996, 41, 159-169. [CrossRef]

19. Benoit, D.; Regolini, J.; Morin, P. Hydrogen desorption and diffusion in PECVD silicon nitride. Application to passivation of CMOS active pixel sensors. Microelectron. Eng. 2007, 84, 2169-2172. [CrossRef]

20. Broas, M.; Jiang, H.; Graff, A.; Sajavaara, T.; Vuorinen, V.; Paulasto-Kröckel, M. Blistering mechanisms of atomic-layer-deposited $\mathrm{AlN}$ and $\mathrm{Al}_{2} \mathrm{O}_{3}$ films. Appl. Phys. Lett. 2017, 111, 141606. [CrossRef]

21. Li, S.; Yang, N.; Yuan, X.; Ye, X.; Wang, L.; Zheng, F.; Liu, C.; Li, H. Plasma-induced damage and annealing repairing in $\mathrm{ALD}-\mathrm{Al}_{2} \mathrm{O}_{3} / \mathrm{PECVD}-\mathrm{SiNx}$ stacks. Mater. Sci. Semicond. Process. 2019, 100, 214-219. [CrossRef]

22. Reichel, C.; Reusch, M.; Kotula, S.; Granek, F.; Richter, A.; Hermle, M.; Glunz, S.W. Insulating and passivating plasma-enhanced atomic layer deposited aluminum oxide thin films for silicon solar cells. Thin Solid Film. 2018, 656, 53-60. [CrossRef]

23. Bae, S.; Kim, S.M.; Lee, K.D.; Kim, Y.D.; Park, S.; Kang, Y.; Lee, H.S.; Kim, D. Effects of Pre-annealing on Firing Stability of Atomic Layer-Deposited $\mathrm{Al}_{2} \mathrm{O}_{3}$. Isr. J. Chem. 2015, 55, 1075-1080. [CrossRef]

24. Werner, F.; Veith, B.; Zielke, D.; Kühnemund, L.; Tegenkamp, C.; Seibt, M.; Brendel, R.; Schmidt, J. Electronic and chemical properties of the c-Si/ $\mathrm{Al}_{2} \mathrm{O}_{3}$ interface. J. Appl. Phys. 2011, 109, 113701. [CrossRef]

(C) 2019 by the authors. Licensee MDPI, Basel, Switzerland. This article is an open access article distributed under the terms and conditions of the Creative Commons Attribution (CC BY) license (http://creativecommons.org/licenses/by/4.0/). 